\title{
Etiologic Evaluation of Severe Short Stature in Children at a Tertiary Pediatric Endocrinology Centre
}

\author{
Utkucan Uçkun ๑ \\ Firdevs Baş $\oplus^{\circ}$ \\ Şükran Poyrazoğlu $\odot$ \\ Mine Şükür $\oplus^{\oplus}$ \\ Feyza Darendeliler $\odot$ \\ Rüveyde Bundak $\odot$
}

\section{Üçüncü Basamak Bir Pediatrik Endokrinoloji \\ Merkezinde İzlenen Ağır Boy Kısalığı \\ Vakalarının Etiyolojik Değerlendirmesi}

\section{ABSTRACT}

Objective: The aim of this study was to describe the characteristics and the etiological profile of children with severe short stature evaluated at a tertiary Pediatric Endocrinology centre in Istanbul.

Method: Randomly selected 500 patients with the diagnosis of severe short stature height SDS<-3SD) were selected for this study. Among those, 320 patients with at least 12 months of follow-up were included.

Results: Among these patients pathological short stature was diagnosed in $94.1 \%$. Endocrine disorders (50.9\%) was found to be the leading cause among pathological short stature; followed by specific syndromes and chromosomal abnormalities (13.2\%), disproportionate short stature (12.8\%), chronic diseases and malnutrition (12.8\%), small for gestational age (SGA) with failure of catch-up growth (3.8\%) and psychosocial short stature (0.6\%). Of those with endocrine disorders; the most common etiology was growth hormone deficiency (GHD) (95.2\%).

Conclusion: Pathological causes should be ruled out in children with severe short stature. Our results showed that the most common cause was GHD among all subjects.

Keywords: Severe short stature, children, etiology, growth hormone deficincy

Öz

Amaç: Araştırmamızın amacı İstanbul'da üçüncü basamak bir Pediatrik Endokrinoloji merkezinde izlenen ağır boy kısalığı olgularının etiyolojik profilini ve karakteristiklerini incelemektir.

Yöntem: Rastgele seçilen 500 ağır boy kısalığı (boy SDS <-3SD) vakasından izlem süresi 12 ay ve üzeri olan 320 hasta çalışmaya alınmıştır.

Bulgular: Vakaların \%94.1'inde patolojik boy kısalığı saptanmıştır. Patolojik boy kısalıklarında en sık etiyolojik neden endokrin bozukluklar $(\% 50,9)$ olarak saptanmıştır. Bunu sırasıyla spesifik sendromlar ve kromozom anomalileri $(\% 13,2)$, orantısız boy kısalıkları (\%12,8), kronik hastalıklar ve malnütrisyon $(\% 12,8)$, catch-up büyümeyi yakalayamayan gebelik yaşına göre küçük (SGA) vakalar $(\% 3,8)$ ve psikososyal boy kısalığı $(\% 0,6)$ izlemektedir. Endokrin bozukluklar içinde en sık etiyolojik neden büyüme hormonu eksikliğidir (\%95,2).

Sonuç: Ağır boy kısalığı olan çocuklarda patolojik boy kısalığı nedenleri dışlanmalıdır. Araştırmamız ağır boy kısalığı olgularında en sık etiyolojik nedenin endokrin bozukluklar olduğunu göstermiştir. Gerek tüm olgularda gerek de endokrin bozukluklar içinde en sık etiyolojik neden büyüme hormonu eksikliği olarak saptanmıştır.

Anahtar kelimeler: Ağır boy kısalığı, çocuklar, etiyoloji, büyüme hormonu eksikliği
Alındığı tarih: 12.04.2019

Kabul tarihi: 28.06.2019

Yayın tarihi: 31.08.2019

Utkucan Uçkun

i. Ü. İstanbul Tıp Fakültesi Çocuk Sağlığı ve Hastalıkları ABD İstanbul - Türkiye

utkucan.uckun@istanbul.edu.tr ORCID: 0000-0001-9731-154X

F. Baş 0000-0001-9689-4464 Ş. Poyrazoğlu 0000-0001-6806-9678

M. Şükür 0000-0003-2769-0526 F. Darendeliler 0000-0003-4786-0780 i. Ü. Istanbul Tıp Fakültesi Pediatrik Endokrinoloji Anabilim Dalı İstanbul - Türkiye

R. Bundak 0000-0001-5097-6448 Girne Üniversitesi Tıp Fakültesi Pediatrik Endokrinoloji Anabilim Dalı Girne - KKTC 


\section{INTRODUCTION}

Short stature is a common pediatric endocrine problem. There are reports, showing that it is one of the chief complaints for pediatric endocrine clinic admissions in Turkey ${ }^{(1)}$.

Growth depends on environmental factors, such as nutrition, psychosocial and hygienic conditions together with genetics and hormonal influences (2). Normal growth is regarded as a sign of a child's physical and mental well-being. Various factors interfere with the normal linear growth of a child; such as systemic diseases, nutritional and psychosocial deprivation, endocrinological problems, various dysmorphologies, metabolic disorders and chromosomal abnormalities ${ }^{(3-5)}$. Normal (non-pathological) variants of growth; familial short stature and constitutional delay of growth and puberty are the most common causes of short stature ${ }^{(2,4-8)}$. These diagnoses are classified as idiopathic short stature according to the recent European Society for Paediatric Endocrinology (ESPE) classification ${ }^{(9)}$.

In 2000, the American Academy of Pediatrics acknowledged the importance of growth, by recommending regular monitorization of growth during childhood until the age of 21 years ${ }^{(10)}$. The growth rate should be measured at certain intervals to avoid unnecessary, non-cost effective laboratory investigations; without causing a delay in diagnosis.

Short stature is defined as a height below the 3rd centile or less than -2 standard deviation score (SDS) of children of the same sex, age and race, whereas severe short stature is defined as a height below -3SD of children of the same sex, age and race. The likelihood of finding an organic cause of short stature in children with a height between -2 and -3 SDS is only $10 \%$; whereas when height is below -3 SDS, organic causes may constitute up to $58 \%$ of all etiologies ${ }^{(10-13)}$. There are several reports conducted on children with a height between -2SDS and -3 SDS, which show that the most common etiological causes for short stature in Turkish children are normal variants of growth ${ }^{(14-16)}$.

In this study, we aimed to describe the characteristics and the etiological profile of children with severe short stature (height SD <-3SDS) evaluated in a pediatric endocrinology clinic of a tertiary center. Auxological, demographic data and laboratory results were presented.

\section{MATERIALS AND METHODS}

This retrospective study was conducted at Pediatric Endocrine Clinic of Istanbul University, Istanbul Faculty of Medicine. Five hundred patients with the diagnosis of severe short stature (height $\mathrm{SD}<-3 \mathrm{SDS}$ ) were randomly selected. Among them, 320 patients with at least 12 months of follow-up were included in this study.

\section{Data collection}

Personal identity records (birth dates, addresses, phone numbers), the presence of parental consanguinity, mother's age at menarche, history of short stature and/or pubertal delay in the family, other familial diseases, history of precocious puberty, heights of both mothers and fathers, the chief complaint of the patient at admission, mode of delivery, gestational age, anthropometric values at birth, birth complications, nutritional history, neuromotor developmental history, additional diseases and previous medications were all recorded from patients' files.

The anthropometric measurements, physical examination and pubertal findings as well as bone ages at admission and follow-up were recorded from the files.

Onset of puberty was defined based on development of breasts in females and a testicular volume of over 4 $\mathrm{ml}$ in males. Puberty was considered to be delayed with no sign of puberty at the age of 14 in males and at the age of 13 in females ${ }^{(17)}$. Pubertal development was assessed by Marshall and Tanner staging ${ }^{(18,19)}$. 
Patients were divided into 2 groups according to Tanner staging to be used in Tables; as Stage 1 (prepubertal) and Stage $>1$ (pubertal).

The ages of all patients at admission were calculated and recorded as decimal years. Patients were divided into three groups according to their ages at admission ( $<5$ years, $5-10$ years and $>10$ years).

\section{Anthropometric measurements}

\section{- Height, weight and head circumference}

All data regarding height, weight and head circumference at admission were collected from patients' files. The height measurements of the children and their parents were done according to the standard measurement rules by using a Harpenden stadiometer by the same auxologist (MŞ). Weight measurements were done by using a scale which is sensitive to 100 grams. Body mass indicies (BMIs) of the patients were calculated by dividing weight of the patients by square of their height $\left(\mathrm{kg} / \mathrm{m}^{2}\right)$. Height, weight and BMI SDS scores were calculated according to Turkish standards proposed by Neyzi et al ${ }^{(20-22)}$ (Büyüyorum v1.3 programme was used for calculations). According to BMI SDS, patients were divided into 4 groups as recommended by World Health Organization (WHO) ${ }^{(23,24)}$ as underweight $(<-2 \mathrm{SD})$, normal (between -2SD and +1SD), overweight (between +1SD and +2SD) and obese (>+2SD).

Weight for height percentages for each patient were calculated and divided into 4 groups as recommended by McLaren and Read ${ }^{(25)}$ : Malnutrition (<90\%), normal (90-110\%), overweight (111-120\%) and obese (>120\%).

The SDS of birth weight, height and head circumference were calculated according to the revised Fenton growth chart. For calculation, the Peditools Fenton 2013 program was used ${ }^{(16)}$.

Patients were divided into three groups; appropriate for gestational age (AGA), small for gestational age
(SGA) and large for gestational age (LGA). Birth weight and/or length were between -2SD and +2SD in AGA, less than -2SD in SGA and greater than +2SD in LGA groups.

\section{- Target height calculation}

Target height values for patients, of whom parental height values were available were calculated according to Tanner method ${ }^{26)}$. The SDS of these values were calculated by using Turkish standards ${ }^{(20-22)}$.

\section{- Predicted adult height calculation}

The predicted adult height (PAH) for each patient was calculated with Bayley-Pinneau method by using Greulich-Pyle atlas (27). The predicted adult height could not be calculated in males with a bone age below 7 years and in females with a bone age below 6 years. The SDS of predicted adult height values were calculated according to Turkish standards ${ }^{(20-22)}$.

\section{Formation of etiology groups}

The etiology groups for short stature were designated according to the classification recommended by the recent ESPE classification list and by Neyzi et al ${ }^{(9,17)}$, which were further divided into 8 main groups to be used in comparison tables according to the recent ESPE classification list ${ }^{(9)}$.

Group 1: Idiopathic short stature

Group 2: Disproportionate short stature (skeletal dysplasias, irradiation, rickets)

Group 3: Small for gestational age (SGA) with failure of catch-up growth and no specific underlying etiology found

Group 4: Specific syndromes and chromosomal abnormalities

Group 5: Endocrine disorders

Group 6: Psychosocial disorders

Group 7: Chronic diseases and malnutrition

Group 8: Undiagnosed

Since smaller number of patients were included in Group 6, and Group 8 constituted of undiagnosed cases due to insufficient data, these groups were not used in comparison tables. 
The definition of idiopathic short stature was based on the exclusion of other likely causes of short stature, and inclusion of the following criteria; normal size at birth (> -2 SDS) for gestational age, normal body proportions, lack of any evidence of chronic organic disease, psychiatric disorder, severe emotional disturbance, and hormonal deficiency., normal food intake.The tempo of growth throughout the growth process may either be slow or normal ${ }^{(9)}$. This group includes familial short stature with normal or delayed puberty and non-familial short stature with normal or delayed (constitutional delay of growth and puberty) puberty.

\section{Laboratory tests and methods}

\section{Calculation of bone age and bone age delay}

Calculation of both the bone age and the bone age delay was performed using Greulich-Pyle atlas. The delay in bone age was divided into 2 main groups to be used in comparison tables; bone age delays as $<2$ and $\geq 2$ years.

\section{Laboratory tests for short stature}

Routine laboratory tests performed for the evaluation of short stature were recorded from patients' files including: complete blood count, biochemical tests (blood urea nitrogen, creatinine, alanine amino transferase, aspartate amino transferase, albumin, electrolytes, blood glucose), erythrocyte sedimentation rate, urinalysis, stool sample analysis (stool pH, steatocrit, stool reducing substance), thyroid function tests (free thyroxine-fT4 and thyroid stimulating hormone-TSH), antigliadin IgA, antiendomisium IgA and $\mathrm{G}$, tissue transglutaminase (if available) serum prolactin, cortisol, luteinizing hormone (LH), follicule stimulating hormone (FSH), estrogen, testosterone values, karyotype, spesific molecular analysis, endoscopic findings, pituitary and/or cranial computed tomography (CT) and/or magnetic resonance imaging (MRI) findings, pelvic, abdominal or thyroid ultrasonographic findings, echocardiography, bone mineral density, skeletal graphies and growth hormone stimulation test results.

\section{Hormonal tests and methods}

\section{Serum IGF-1 values}

The IGF-1 values were recorded from patients' files. In our clinic, Liaison ${ }^{\circledR}$ IGF-1 (313231) CLIA (chemiluminescent immunoassay) test (DiaSorin, Sallugia, Italy) is used to assess the IGF-1 values in $\mathrm{ng} / \mathrm{ml}$. The SD scores of the results were calculated using instruction manual of the kit.

\section{Serum IGFBP-3 values}

The IGFBP-3 values were recorded from patients' files. In our clinic, IMMULITE ${ }^{\circledR}$ test (Siemens, Malvern, PA, USA) is used to assess the IGFBP-3 values in ng/ $\mathrm{ml}$. The SD scores of the results were calculated using instruction manual of the kit.

\section{Growth hormone provocation tests}

GHD was defined as a serum peak $\mathrm{GH}$ concentration $<10 \mathrm{ng} / \mathrm{mL}$ on provocation at two separate stimulation tests. GH stimulation tests were performed with various stimuli, such as insulin, L-dopa, clonidin, and glucagon. In prepubertal boys over 11 years, intramuscular testosterone depot injections were performed 7-10 days before GH testing; and in prepubertal girls over 10 years, oral conjugated estrogen was prescribed for 3 days before testing.

\section{Statistics}

For statistical analysis SPSS 21.0 programme was used. Pearsons's chi-square and Fisher's exact tests were applied to sets of categorical data.Paired t-test was performed for comparison and comparisons among groups were performed using analysis of variance. LSD test was used to find out the group that differs from the others. Differences were regarded as significant when $P$ value was $<0.05$.

\section{RESULTS}

Five hundred (253M/247F) patients with the diagnosis of severe short stature (height SDS <-3SD) were selected for this study. Among these, 320 (168M/152F, 
mean age $8.4 \pm 4.5$ years) patients followed up for at least 12 months were included in this study. The mean follow-up period of the patients was $4.9 \pm 3.4$ years (1-20.9 years).

Birth records of the patients revealed that the mean gestational age of 312 of 320 patients was $39.1 \pm 2.4$ weeks. The mean birth weight of 258 of 320 patients was $2803.7 \pm 761.6$ grams and the mean birth weight SD score was $-1.1 \pm 1.8 \mathrm{SD}$. We could only reach the birth length records of 114 patients and the mean SD score of birth height was $-1.3 \pm 1.9$ SD. There were only birth head circumference data of 9 patients. No statistical difference was found when patients' genders were compared for gestational age, birth weight SDS, birth height SDS and birth head circumference SDS ( $p>0.05)$.

More than half (56.6\%) of 258 patients with known birth weight records were found to be AGA, $36.8 \%$ of them were SGA and $6.6 \%$ of them were LGA. There was no statistical difference in birth weights adjusted for gestational age distribution between genders $(p>0.05)$.

History of parental consanguinity was found in $39.7 \%$ of 320 patients, which was slightly higher among female patients $(p=0.052)$.

When patients were classified according to their short stature etiologies, $94.1 \%$ of them had patho- logical causes in origin (Figure 1). Endocrine disorders constituted the major cause with a percentage of 50.9. Specific syndromes and chromosomal abnormalities were the second most common cause. (13.2\%) GHD was found to be the most common cause of short stature in the group of endocrinological disorders (95.2\%) (Figure 1 and Table 1).

Female children were more numerous than male children in the group of Specific syndromes and chromosomal abnormalities' $(p=0.045)$. There was no statistical difference in other etiology groups $(p>0.05)$.

The age at admission was found to be below 5 years in etiology groups of 'Disproportionate short stature (skeletal dysplasias, irradiation, rickets)' and 'SGA with failure of catch-up growth'. 'Endocrine disorders' group tended to be admitted over 5 years of age whereas 'Chronic diseases and malnutrition' group tended to be referred relatively late with an age at admission over 10 years $(p<0.05)$.

There was no statistical difference in the distribution of parental consanguinity among short stature etiology groups ( $p>0.05)$.

The mean gestational age at birth of 'Specific syndromes and chromosomal abnormalities' group was

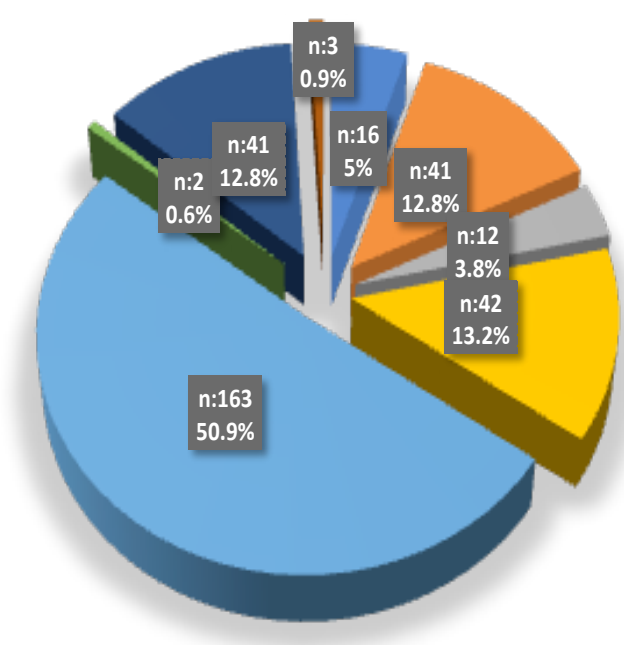

Figure 1. Distribution of etiology in short stature (n, \%). *Idiopathic short stature: Non-pathological short stature
GROUP 1 : Idiopathic short stature

GROUP 2 : Disproportionate short stature

GROUP 3 : Small for gestational age (SGA) with failure of catch-up growth

GROUP 4 : Specific syndromes and chromosomal abnormalities

GROUP 5 : Endocrine disorders

GROUP 6 : Psychosocial disorders

- GROUP 7 : Chronic diseases and malnutrition

GROUP 8 : Undiagnosed 
Table 1. Subgroup distributions among short stature etiology groups.

\begin{tabular}{|c|c|c|}
\hline & \multicolumn{2}{|c|}{ Subgroup } \\
\hline & $\mathbf{n}$ & $\%$ \\
\hline GROUP 1: Idiopathic short stature & 16 & \\
\hline - Familial short stature with normal pubertal onset & 5 & 31.2 \\
\hline - Familial short stature with delayed pubertal onset & 1 & 6.3 \\
\hline - Non-familial short stature with delayed pubertal onset (constitutional growth of delay and puberty) & 3 & 18.8 \\
\hline - Non-familial short stature, onset of puberty not yet known & 7 & 43.7 \\
\hline GROUP 2: Disproportionate short stature & 41 & \\
\hline Skeletal dysplasias & 39 & \\
\hline - Achondroplasia & 11 & 26.9 \\
\hline - Hypochondroplasia & 7 & 17.1 \\
\hline - Metaphyseal and epiphyseal dysostosis & 10 & 24.4 \\
\hline - Others & 10 & 24.4 \\
\hline Irradiation & 1 & 2.4 \\
\hline Rickets & 2 & 4.8 \\
\hline GROUP 3: SGA with failure of catch-up growth & 12 & \\
\hline GROUP 4: Specific syndromes and chromosomal abnormalities & 42 & \\
\hline Chromosomal abnormalities & 6 & \\
\hline - Down syndrome & 3 & 7.2 \\
\hline - Turner syndrome & 1 & 2.4 \\
\hline - Others & 2 & 4.8 \\
\hline Specific syndromes & 36 & \\
\hline - Cornelia de Lange syndrome & 1 & 2.4 \\
\hline - Russell-Silver syndrome & 5 & 11.2 \\
\hline - Robinow syndrome & 1 & 2.4 \\
\hline - Noonan syndrome & 6 & 14.4 \\
\hline - Rothmund-Thomson syndrome & 1 & 2.4 \\
\hline - Prader-Willi syndrome & 1 & 2.4 \\
\hline - Seckel syndrome & 2 & 4.8 \\
\hline - Others & 19 & 45.1 \\
\hline GROUP 5: Endocrine disorders & 163 & \\
\hline - Growth Hormone Deficiency (GHD) & 155 & 95.2 \\
\hline - Primary hypothyroidism & 6 & 3.6 \\
\hline - Cushing's disease & 2 & 1.2 \\
\hline GROUP 6: Psychosocial disorders & 2 & \\
\hline GROUP 7: Chronic diseases and malnutrition & 41 & \\
\hline Malnutrition & 7 & 17.2 \\
\hline Chronic diseases & 34 & \\
\hline - Gastrointestinal system disorders & 5 & \\
\hline Crohn's disease & 1 & 2.4 \\
\hline Celiac disease & 2 & 4.9 \\
\hline Short bowel syndrome & 2 & 4.9 \\
\hline - Renal disorders & 10 & \\
\hline Congenital anomalies & 2 & 4.9 \\
\hline Chronic glomerulonephritis & 3 & 7.3 \\
\hline Pyelonephritis, obstructive uropathy & 3 & 7.3 \\
\hline Renal tubular acidosis & 2 & 4.9 \\
\hline - Chronic liver diseases & 1 & 2.4 \\
\hline - Cardiac diseases & 2 & \\
\hline PDA & 1 & 2.4 \\
\hline VSD & 1 & 2.4 \\
\hline - Chronic anemias & 3 & 7.3 \\
\hline - Metabolic disorders & 9 & 22 \\
\hline - Pulmonary disorders & 3 & 7.3 \\
\hline - Others & 1 & 2.4 \\
\hline GROUP 8: Undiagnosed & 3 & \\
\hline
\end{tabular}

SGA: small for gestational age, PDA: patent ductus arteriosus, VSD: ventricular septal defect 
U. Uçkun ve ark., Etiologic Evaluation of Severe Short Stature in Children at a Tertiary Pediatric Endocrinology Centre

Table 2. Anthropometric data comparisons between groups.

\begin{tabular}{|c|c|c|c|c|c|c|c|c|c|}
\hline & Group 1 & Group 2 & Group 3 & Group 4 & Group 5 & Group 7 & $F$ & $p$ & df \\
\hline $\begin{array}{l}\text { Gestational week } \\
\text { (mean } \pm \text { SD) }\end{array}$ & $38.7 \pm 3.3$ & $39.3 \pm 1.5$ & $39.5 \pm 1.7$ & $37.8 \pm 3.7$ & $39.1 \pm 2.2$ & $39.3 \pm 1.9$ & 2.669 & 0.022 & $\begin{array}{l}2>4 \\
3>4 \\
5>4 \\
6>4\end{array}$ \\
\hline $\begin{array}{l}\text { Birth weight SDS } \\
\text { (mean } \pm \text { SD) }\end{array}$ & $0.2 \pm 2.1$ & $-1.1 \pm 1.3$ & $-3.3 \pm 1.4$ & $-1.6 \pm 2.2$ & $-0.9 \pm 1.7$ & $-0.5 \pm 1.5$ & 6.878 & 0.000 & $\begin{array}{l}1>2 \\
1>3 \\
2>3 \\
4>3 \\
5>3 \\
6>3 \\
1>4 \\
5>4 \\
6>4 \\
1>5\end{array}$ \\
\hline $\begin{array}{l}\text { Birth lenght SDS } \\
\text { (mean } \pm S D)\end{array}$ & $-0.8 \pm 0.3$ & $-1.3 \pm 1.7$ & $-2.9 \pm 1.6$ & $-2.9 \pm 2.5$ & $-0.7 \pm 1.4$ & $-0.4 \pm 1.2$ & 6.656 & 0.000 & $\begin{array}{l}5>3 \\
6>3 \\
2>4 \\
5>4 \\
6>4\end{array}$ \\
\hline $\begin{array}{l}\text { Height SDS at admission } \\
(\text { mean } \pm \text { SD) }\end{array}$ & $-3.4 \pm 0.3$ & $-4.3 \pm 1.2$ & $-4.1 \pm 1.0$ & $-4.2 \pm 1.1$ & $-4.1 \pm 0.9$ & $-4.1 \pm 1.3$ & 1.689 & 0.137 & \\
\hline $\begin{array}{l}\text { Weight SDS at admission } \\
\text { (mean } \pm S D)\end{array}$ & $-2.6 \pm 1.4$ & $-2.6 \pm 1.2$ & $-3.8 \pm 1.3$ & $-3.5 \pm 1.8$ & $-2.8 \pm 1.3$ & $-3.5 \pm 1.4$ & 3.992 & 0.002 & $\begin{array}{l}1>3 \\
2>3 \\
5>3 \\
1>4 \\
2>4 \\
5>4 \\
1>6 \\
2>6 \\
5>6\end{array}$ \\
\hline $\begin{array}{l}\text { Head circumference SDS at } \\
\text { admission } \\
\text { (mean } \pm S D)\end{array}$ & $-1.9 \pm 0.4$ & $-0.9 \pm 1.8$ & $-2.6 \pm 2.1$ & $-2.9 \pm 1.9$ & $-1.9 \pm 1.4$ & $-2.4 \pm 1.3$ & 5.099 & 0.000 & $\begin{array}{l}2>3 \\
2>4 \\
5>4 \\
2>5 \\
2>6\end{array}$ \\
\hline $\begin{array}{l}\text { BMI SDS at admission } \\
(\text { mean } \pm \text { SD })\end{array}$ & $-0.9 \pm 1.6$ & $0.3 \pm 1.5$ & $-1.3 \pm 1.1$ & $-1.2 \pm 2.2$ & $-0.4 \pm 1.3$ & $-1.2 \pm 1.4$ & 7.062 & 0.000 & $\begin{array}{l}2>1 \\
2>3 \\
2>4 \\
5>4 \\
2>5 \\
2>7 \\
5>7\end{array}$ \\
\hline $\begin{array}{l}\text { Weight for height percentage } \\
\text { at admission } \\
\text { (mean } \pm \text { SD) }\end{array}$ & $100.4 \pm 28.1$ & $104.2 \pm 15.3$ & $87.5 \pm 10.7$ & $95.2 \pm 19.3$ & $103.2 \pm 19.5$ & $94.1 \pm 15.4$ & 3.731 & 0.003 & $\begin{array}{l}2>3 \\
5>3 \\
2>4 \\
5>4 \\
2>7 \\
5>7\end{array}$ \\
\hline $\begin{array}{l}\text { Bone age delay at admission } \\
\text { (mean } \pm \text { SD) }\end{array}$ & $2.2 \pm 1.0$ & $1.5 \pm 1.2$ & $1.8 \pm 1.5$ & $2.1 \pm 1.6$ & $2.9 \pm 1.5$ & $2.8 \pm 1.5$ & 4.299 & 0.001 & $\begin{array}{l}5>1 \\
7>1\end{array}$ \\
\hline $\begin{array}{l}\text { Predicted adult height (PAH) SDS } \\
\text { at admission } \\
\text { (mean } \pm \text { SD) }\end{array}$ & $-1.2 \pm 1.4$ & $-3.5 \pm 1.9$ & $-2.9 \pm 0.7$ & $-2.9 \pm 1.5$ & $-1.9 \pm 1.6$ & $-1.6 \pm 1.8$ & 3.262 & 0.009 & $\begin{array}{l}1>2 \\
5>2 \\
7>2 \\
1>4 \\
7>4\end{array}$ \\
\hline $\begin{array}{l}\text { Target height (TH) SDS } \\
\text { (mean } \pm \text { SD) }\end{array}$ & $-1.7 \pm 0.9$ & $-1.2 \pm 1.6$ & $-1.7 \pm 0.4$ & $-1.1 \pm 0.6$ & $-1.5 \pm 0.8$ & $-1.1 \pm 1.0$ & 1.707 & 0.134 & \\
\hline $\begin{array}{l}\text { Target height minus height } \\
\text { SDS at admission } \\
\text { (mean } \pm \text { SD) }\end{array}$ & $-1.7 \pm 1.1$ & $-3.2 \pm 2.0$ & $-2.7 \pm 1.1$ & $-3.1 \pm 1.4$ & $-2.4 \pm 1.2$ & $-2.9 \pm 1.7$ & 3.266 & 0.007 & $1>2$ \\
\hline
\end{tabular}

SDS: standard deviation score, SD: standard deviation, BMI: body mass index 
statistically lower than those of other short stature etiology groups $(p<0.05)$-except 'Idiopathic short stature' group (Table 2).

The mean birth weight SD score of 'Specific syndromes and chromosomal abnormalities' group was statistically lower than the birth weight SD scores of the groups of 'Idiopathic short stature', 'Endocrine disorders' and 'Chronic diseases and malnutrition'. On the other hand, the mean birth weight SD score of 'Idiopathic short stature' group was statistically higher than the mean birth weight SD scores of the groups of 'Endocrine disorders' and 'Disproportionate short stature (skeletal dysplasias, irradiation, rickets) $(p<0.001)$ (Table 2).

The mean birth length SD score of 'Specific syndromes and chromosomal abnormalities' group was statistically lower than those of 'Disproportionate short stature (skeletal dysplasias, irradiation, rickets)', 'Endocrine disorders' and 'Chronic diseases and malnutrition' groups $(p<0.001)$ (Table 2$)$.

The mean weight SD scores of 'SGA with failure of catch-up growth', 'Specific syndromes and chromosomal abnormalities' and 'Chronic diseases and malnutrition' groups at admission were statistically lower than those of other etiology groups $(p=0.002)$ (Table 2).

The mean head circumference SD score of 'Disproportionate short stature (skeletal dysplasias, irradiation, rickets)' etiology group was statistically higher than 'SGA with failure of catch-up growth', 'Specific syndromes and chromosomal abnormalities' and 'Chronic diseases and malnutrition' groups' at admission. The mean head circumference SD score of 'Endocrine disorders' was also found to be statistically higher than 'Specific syndromes and chromosomal abnormalities' etiology group's at admission $(p<0.001)$ (Table 2$)$.

The mean body mass index (BMI) SD score of 'Disproportionate short stature (skeletal dysplasias, irradiation, rickets)' etiology group was statistically higher than those of other etiology groups at admission. The mean body mass index (BMI) SD score of 'Endocrine disorders' etiology group was statistically higher than 'Specific syndromes and chromosomal abnormalities' and 'Chronic diseases and malnutrition' groups' at admission $(p<0.001)$ (Table 2$)$.

The mean weight for height percentage of both 'Disproportionate short stature (skeletal dysplasias, irradiation, rickets)' and 'Endocrine disorders' etiology groups were statistically higher than those of 'SGA with failure of catch-up growth', 'Specific syndromes and chromosomal abnormalities' and 'Chronic diseases and malnutrition' groups at admission $(p<0.05)$ (Table 2).

Patients within 'Disproportionate short stature (skeletal dysplasias, irradiation, rickets)', 'Specific syndromes and chromosomal abnormalities', 'Endocrine disorders' and 'Chronic diseases and malnutrition' groups were found to be normal according to their interpreted BMI SD scores at admission $(p<0.05)$.

Patients within 'Disproportionate short stature (skeletal dysplasias, irradiation, rickets)' and 'Endocrine disorders' groups were found to be also normal according to their interpreted weight for height percentage values at admission. However patients within 'Specific syndromes and chromosomal abnormalities' group had malnutrition according to their weight for height percentage values at admission $(p<0.05)$.

Patients in 'Idiopathic short stature' group were more likely to be in pubertal stage of 2 and over at admission ( $p: 0.001)$.

The mean bone age delay at admission among 'Endocrine disorders' and 'Chronic diseases and malnutrition' groups; were found to be higher than other etiology groups' (p:0.001) (Table 2).

The mean predicted adult height (PAH) SD scores of 
'Idiopathic short stature' and 'Chronic diseases and malnutrition' groups at admisson were statistically higher than those of 'Disproportionate short stature (skeletal dysplasias, irradiation, rickets)' and 'Specific syndromes and chromosomal abnormalities' groups. Moreover, the mean PAH SD score of 'Endocrine disorders' group was statistically higher than 'Disproportionate short stature (skeletal dysplasias, irradiation, rickets)' group's ( $p<0.05)$ (Table 2).

There were no significant statistical difference among etiology groups according to mean target height SD scores ( $p>0.05$ ) (Table 2).

The mean SD scores gathered after extraction between target height SD scores and height SD scores at admission revealed that the mean extracted SD score of 'Idiopathic short stature' group was statistically higher than that of 'Disproportionate short stature (skeletal dysplasias, irradiation, rickets)' group $(p<0.05)$ (Table 2$)$.

Bone age delay below 2 years was more common in 'Disproportionate short stature (skeletal dysplasias, irradiation, rickets)' group; whereas bone age delay of 2 years and over was more common in 'Endocrine disorders' group $(p<0.05)$.

Mean IGF-1 SD score of 'Disproportionate short stature (skeletal dysplasias, irradiation, rickets)' group was found to be higher than that of, Chronic diseases and malnutrition' group. Additionally it was statistically higher in 'Specific syndromes and chromosomal abnormalities' group than that in 'Endocrine disorders' group $(p<0.05)$.

Mean IGFBP-3 SD scores of 'Disproportionate short stature (skeletal dysplasias, irradiation, rickets)', 'Specific syndromes and chromosomal abnormalities' and 'SGA with failure of catch-up growth 'groups were statistically higher than those of 'Endocrine disorders' and 'Chronic diseases and malnutrition' groups. 'Disproportionate short stature (skeletal dysplasias, irradiation, rickets)' group's score was also higher than those of 'Idiopathic short stature' and 'Specific syndromes and chromosomal abnormalities' groups $(p<0.001)$.

\section{DISCUSSION}

Our study showed that children with a height SDS less than -3SDS had mostly pathological short stature and the most frequent etiological cause was endocrine disorders. Furthermore, GHD was the most common diagnosis among endocrine disorders. Our results reflect the etiologies of severe short stature in patients referred to tertiary center. The findings may change according to the study center. The endocrinological causes outnumber non-endocrinological causes based on research data at a tertiary endocrinology units, whereas normal variants of growth constitute the leading causes of short stature in general pediatric population and/or communitybased researches ${ }^{(14,15,28-36)}$. The results of different studies are shown in Table 3.

This study has some similarities with the study by Zargar et al. ${ }^{(35)}$ in terms of having a relatively long follow-up period, dealing with cases with a height below -3SD and being held at a tertiary centre. Like them, we showed that the most common single etiology of severe short stature was GHD. However our GHD percentage was higher than that of Zargar et al ${ }^{(35)}$. Moreover pathological causes of short stature was found to be responsible from $94.1 \%$ of all cases in this study. This rate is higher than those of any other studies. The most common non-endocrinological causes of pathological short stature in our study population were specific syndromes and chromosomal abnormalities. There are studies showing renal tubular acidosis (RTA) ${ }^{(33,35)}$ and celiac disease ${ }^{(34,37)}$ as the most common non-endocrinological causes of pathological short stature. This could be related to the referral pattern of patients to our endocrinology clinic. Those non-endocrinological cases might directly be referred to related specialists.

In this study, non-familial short stature with unknown 
Table 3. Etiological distribution of short stature in different studies.

\begin{tabular}{|c|c|c|c|c|c|c|c|c|c|}
\hline Study & $\begin{array}{l}\text { Patient } \\
\text { collection }\end{array}$ & $\begin{array}{l}\text { Year study } \\
\text { conducted }\end{array}$ & $\begin{array}{l}\text { Study population } \\
\text { (number of } \\
\text { participants) }\end{array}$ & Study type & $\mathrm{M}: \mathrm{F}$ & Study centre & $\begin{array}{l}\text { Most common } \\
\text { etiology }\end{array}$ & $\begin{array}{l}\text { Normal variants } \\
\text { of growth (\%) }\end{array}$ & $\begin{array}{c}\text { Pathological } \\
\text { causes (\%) }\end{array}$ \\
\hline Lindsay et al. ${ }^{(29)}$ & $<3$ rd centile & 1992 & $\begin{array}{c}555 \text { out of } \\
123,948\end{array}$ & $\begin{array}{l}\text { Prospective } \\
\text { prevalence }\end{array}$ & $2.7: 1$ & Community-based & FSS (37\%) & 85.9 & 14.1 \\
\hline Song et al. ${ }^{\left({ }^{(0)}\right)}$ & $\leq-3 S D S />-3 S D S$ & 2010-2012 & $\begin{array}{l}356 \text { out of } 3,371 \\
(101 / 255)\end{array}$ & Retrospective & $\begin{array}{c}0.93: 1 \\
(0.74: 1 / 1.02: 1)\end{array}$ & $\begin{array}{l}\text { Tertiary pediatric } \\
\text { centre }\end{array}$ & $\begin{array}{c}\text { GHD }(20.8 \%) / F S S \\
(25.1 \%)\end{array}$ & $44.7(32.6 / 49.4)$ & $\begin{array}{c}54.2 \\
(67.4 / 50.6)\end{array}$ \\
\hline Strufaldi et al. ${ }^{(31)}$ & $<5$ th centile & $1997-2001$ & 99 out of 152 & Descriptive & $1.71: 1$ & $\begin{array}{l}\text { Tertiary pediatric } \\
\text { centre }\end{array}$ & $\mathrm{FSS}+\mathrm{CGD}(58 \%)$ & 58 & 29 \\
\hline Demirel et al. ${ }^{(15)}$ & $<-2$ SDS & $2002-2004$ & 385 & Retrospective & $1.02: 1$ & $\begin{array}{l}\text { Tertiary endocrine } \\
\text { centre }\end{array}$ & $\begin{array}{l}\text { Normal variants of } \\
\text { growth }(71.1 \%)\end{array}$ & 71.1 & 28.9 \\
\hline Shiva et al. ${ }^{(32)}$ & $<-2$ SDS & $2005-2006$ & 379 & $\begin{array}{l}\text { Descriptive- } \\
\text { analytic and } \\
\text { prospective }\end{array}$ & $1.02: 1$ & $\begin{array}{l}\text { Tertiary endocrine } \\
\text { centre }\end{array}$ & $\begin{array}{l}\text { Normal variants of } \\
\text { growth }(53.3 \%)\end{array}$ & 53.3 & 35.2 \\
\hline Moayeri et al. ${ }^{(33)}$ & $<-2$ SDS & $1995-2001$ & 426 & $\begin{array}{l}\text { Prospective and } \\
\text { descriptive }\end{array}$ & $1.76: 1$ & $\begin{array}{l}\text { Tertiary endocrine } \\
\text { centre }\end{array}$ & $\begin{array}{l}\text { Normal variants of } \\
\text { growth }(53 \%)\end{array}$ & 53 & 47 \\
\hline Lashari et al. ${ }^{(34)}$ & $\begin{array}{l}<-2 \text { SDS }(73 \% \\
<-2.67 S D S)\end{array}$ & 2007 & 100 & $\begin{array}{l}\text { Descriptive cross } \\
\text { sectional }\end{array}$ & $1.08: 1$ & $\begin{array}{l}\text { Tertiary endocrine } \\
\text { centre }\end{array}$ & $\begin{array}{l}\text { Normal variants of } \\
\text { growth }(55 \%)\end{array}$ & 55 & 45 \\
\hline Zargar et al. ${ }^{(35)}$ & $<-3$ SDS & $1987-1996$ & 193 & Retrospective & $1.12: 1$ & $\begin{array}{l}\text { Tertiary endocrine } \\
\text { centre }\end{array}$ & GHD (22.8\%) & 18.7 & 74.6 \\
\hline Papadimitru et al. ${ }^{(36)}$ & $\leq-3 S D S />-3 S D S$ & $2007-2008$ & $295(35 / 260)$ & Prospective & $\begin{array}{c}1.2: 1 \\
(2.5: 1 / 1.1: 1)\end{array}$ & $\begin{array}{l}\text { Tertiary endocrine } \\
\text { centre }\end{array}$ & $\begin{array}{c}\text { GHD }(\% 36.1) / F S S \\
(41.2 \%)\end{array}$ & $40 / 80.8$ & $60 / 19.2$ \\
\hline
\end{tabular}

FSS: familial short stature, SDS: standard deviation score, GHD: growth hormone deficiency, CGD: constitutional delay of growth and puberty.

onset of puberty was found to be the most common cause of idiopathic short stature (43.7\%), which in fact was not a consistent finding with the literature. Indeed familial short stature with normal or delayed pubertal onset is the most common cause of idiopathic short stature indicated in the literature ${ }^{(30,36)}$.

This study showed that skeletal dysplasias (98.2\%) are the most common causes of disproportionate short stature, and achondroplasia was found to be the leading cause (28.2\%) among skeletal dysplasias as a consistent finding with the literature ${ }^{(33)}$.

Noonan (14.4\%) and Russell-Silver syndromes (11.2\%) were the most common specific syndromes and chromosomal abnormalities in this study. The relatively less likelihood of finding Turner syndrome in our study population might be linked to the awareness of this syndrome among both pediatricians and the society. These cases might be referred with a height between -2 and -3 SDS.

Metabolic disorders (22\%) and malnutrition (17.2\%) were the most common causes among chronic diseases and malnutrition cases in this study. In Utah study (29), protein-energy malnutrition (PEM) and malabsorption syndromes constituted $10 \%$ of short stature cases. However, they consisted $3.8 \%$ of our study population. The reason of this finding might also be related to differences in study centres. Those cases with malnutrition might be directly referred to pediatric gastroenterologists. Additionally, $16 \%$ of 320 cases were diagnosed as 'underweight' according to their interpreted BMI SD scores in our study population. On the other hand, $32.8 \%$ of our cases were diagnosed as having malnutrition according to their interpreted weight for height percentages. The likelihood of having malnutrition increases when measures are interpreted based on weight for age and/or height for age percentages in our study population. Weight for height percentage is a measure to identify acute malnutrition and there is a two-fold difference between 'underweight' cases in our study population. So it might be of a concern, that there is a need for additional data related to cases with short stature to assess malnutrition in a more objective way.

Some research data demonstrate that male admissions are more common ${ }^{(1,28)}$. There are even data 
claiming that the higher incidence of male admissions is more likely to be linked to the perception of tall men as being more successful, having prestigious jobs and higher incomes in the society ${ }^{(2)}$. However other recent data also claim that there is a decline in male to female ratio because of the perception in social media that thin and tall women are also more successful ${ }^{(11)}$. In this study, the male to female ratio was 1.1:1. This finding is consistent with the findings of Zargar et al. (35) (1.12:1) and Papadimitriou et al. (36) (1.2:1). But it should also be kept in mind that our findings don't represent the general population.

A $39.7 \%$ of 320 our cases had a history of parental consanguinity, which was higher than the average rate in general Turkish population (approx. 20-25\%) (38). The statistically higher proportion of female gender in the specific syndromes and chromosomal abnormalities group might be related to the higher incidence of SHOX deletions on X chromosome than those seen on $Y$ chromosome ${ }^{(39)}$.

In this study, analysis of the distribution of age groups at admission revealed that cases with disproportionate short stature (skeletal dysplasias, irradiation, rickets) and SGA with failure of catch-up growth present at an age below 5 years. This finding could also be regarded as statistically significant for specific syndromes and chromosomal abnormalities group. On the other hand, endocrine disorders present after 5 years of age and cases with chronic diseases\&malnutrition, and also idiopathic short stature present after 10 years of age. Moayeri et al. (33) found that the mean age at admission of cases with skeletal dyplasias and rickets was lower than other etiology groups. The lower mean age at admission of our disproportionate short stature population is consistent with the literature. Song et al. ${ }^{(30)}$ found that the mean age at admission of familial short stature group was statistically higher than that of pathological short stature etiology group. Similiar to their results, the mean age at admission of idiopathic short stature group was statistically higher than that of other etiology groups in our. -except chronic diseases and malnutrition group-

In our study, AGA births in idiopathic short stature group and SGA births in specific syndromes and chromosomal abnormalities group were statistically significantly more numerous. These findings are consistent with the findings of Strufaldi et al. ${ }^{(31)}$. They showed that, patients with familial/constitutional delay of growth were more likely to have birth weight values over 3000 grams and genetic short stature cases have birth weights below 2500 grams. The mean gestational age at birth in specific syndromes and chromosomal abnormalities group was statistically lower than other short stature etiology groups -except idiopathic short stature groups- The mean birth height SD scores of endocrine disorders and chronic diseases and malnutrition etiology groups were statistically higher than SGA with failure of catch-up growth and specific syndromes and chromosomal abnormalities groups' in this study. Moreover cases with disproportionate short stature had higher birth height SD scores relative to specific syndromes and chromosomal abnormalities cases in this study. These findings support the argument that, normal intrauterine growth is mostly independent from fetal pituitary hormones - unlike the critical role of endocrine system in postnatal growth ${ }^{(40,41)}$.

Zargar et al. ${ }^{(35)}$ didn't find a statistical difference in mean height SD scores at admission between normal variants of growth and growth hormone deficiency cases with severe short stature. Like them, we couldn't also find a statistical difference in mean height SD scores at admission between short stature etiology groups.

The mean head circumference SD score of disproportionate short stature etiology group in our study was found to be statistically higher than that found in other groups -except idiopathic short stature etiology group- This finding supports relative macrocephaly, which is a component of skeletal dysplasias (42). Additionally, the mean head circumference SD score 
of endocrine disorders etiology group was statistically higher than that of specific syndromes and chromosomal abnormalities group, which might be linked to the presence of syndromes accompanied with microcephaly in our study population.

Cases with disproportionate short stature and endocrine disorders were found to be normal according to body weight SDS, BMI SDS and weight for height percentages. BMI SD scores of cases with specific syndromes, chromosomal abnormalities, chronic diseases and malnutrition were found mostly within the normal range. This finding might be related to the lower number of malnutrition cases in our chronic diseases and malnutirition group.

In our study, the mean bone age delay (in years) values of endocrine disorders and chronic diseases\&malnutrition groups at admission were statistically higher than those of other groups. Papadimitriou et al. (36) investigated the mean bone age delay between familal short stature, constitiunal delay of growth and growth hormone deficiency groups. In that study, the mean value was statistically lower in cases with familial short stature. Likewise Song et al. ${ }^{(30)}$ found the mean bone age delay of familial short stature cases to be lower than those of cases with constitiunal delay of growth and pathological short stature. In this study, non-familial short stature with unknown pubertal onset and familial short stature with normal pubertal onset cases constituted the majority of our idiopathic short stature population and growth hormone deficiency cases constituted the vast majority of our study population with endocrine disorders, which was consistent with the literature findings.

The mean predicted adult height SD scores of idiopathic short stature and chronic diseases and malnutrition groups were statistically higher than those of disproportionate short stature and specific syndromes and chromosomal abnormalities groups. Moreover the score of endocrine disorders was sta- tistically higher than that of disproportionate short stature. This might be linked to highest bone age delay values seen in endocrine disorders and chronic diseases\&malnutrition cases. Our findings were consistent with the literature in this respect ${ }^{(30,36)}$.

According to two major designated Tanner staging groups, idiopathic short stature cases had a statistically higher distribution in the Tanner stage of 2 and over. This finding might be related to the lack of an underlying endocrine pathology and a relatively late presentation of cases.

In this study, the mean IGF-1 SD scores of the patients with endocrine disorders and chronic diseases and malnutrition were relatively lower as expected. This was true for IGFBP3 as well. It was noteworthy that SGA with failure of catch-up growth had higher mean IGFBP-3 SD score than endocrine disorders group. Song et al. (30) found that the mean serum IGF-1 level of pathological short stature was statistically lower than others' and there was no statistical difference in the mean serum IGFBP-3 level between etiology groups in the same study. On the other hand, Papadimitriu et al. (36) found that the mean serum IGF-1 level of the group with constitutional growth delay was statistically lower compared to other groups. But it should also be kept in mind that, serum IGF-1 and IGFBP-3 levels change according to age and sex. So making comparisons by just looking at the serum levels may lead to wrong interpretations.

According to our study, AGA children presenting over 10 years of age with no history of parental consanguinity have found to be least likely to have pathological causes of short stature

\section{CONCLUSION}

This study is the first study, which deals with only severe short stature cases and their etiological profile in Turkey and it shows that, majority of severe short stature cases have underlying pathologies. 
Among pathological short stature cases, endocrine disorders were the most common causes. Furthermore, growth hormone deficiency was the most common cause among endocrine disorders. The likelihood of diagnosing a pathological cause among children with severe short stature is high. So it would be a reasonable choice to run tests without any delay to identify the underlying etiology. It would be desirable to lower the age of diagnosis in endocrine disorders.

Etik Kurul Onayı: İstanbul Üniversitesi Tıp Fakültesi Etik Kurulu'nun onayı alınmıştır (26.06.2015/1272)

Çıkar Çatışması: Makalenin yazarları arasında çıkar çatışması bulunmamaktadır.

Finansal Destek: Makalenin yazarları finansal destek almamıştır

Hasta Onayı: Araştırmada yer alan vakaların aydınlatılmış onamı alınmamıştır.

Ethics Committee Approval: Approval of the Ethics Committee of Istanbul University Faculty of Medicine was obtained (26.06.2015 / 1272).

Conflict of Interest: The authors declare that they have no conflict of interest.

Funding: The authors have no funding to report.

Informed Consent: Informed consent was not obtained from participants included in the study.

\section{REFERENCES}

1. Sen Y, Bozdag S. The etiological distribution of patients admitted to the pediatric endocrinology clinic. Firat University Journals of Health Sciences 2008;22(2): 53-8.

2. Rosenfield R, Cuttler L. Short stature. In: DeGroot LJ, Jamesan JL, eds. Endocrinology. 4th ed. Philadelphia: WB Saunders, 2001:485-94.

3. Marcovitch H. Failure to thrive. $\mathrm{Br}$ Med J. 1994;308: 35-8.

https://doi.org/10.1136/bmj.308.6920.35

4. Frindik JP, Kemp SF, Hunold JJ. Near adult heights after growth hormone treatment in patients with idiopathic short stature or idiopathic growth hormone deficiency. J Pediatr Endocrinol Metab 2003;16:607-12.

5. Vogiatazi MG, Copland KC. The short child. Pediatr Rev 1998;19:92-9. https://doi.org/10.1542/pir.19-3-92

6. Thomas Aceto JR, Dempsher D. Short stature and slow growth in the young. In: Becker KL, eds. Principles and Practice of Endocrinology and Metabolism. 3rd ed. Philadelphia: Lippincott Williams and Wilkins, 2001:1784-97.

7. Rosenfeld RG. Growth retardation. In: Sperling MA, eds. Pediatric Endocrinology. Philadelphia: WB Saunders, 1996:135-57.

8. Reiter O, Rosenfeld Ron G. Growth retardation. In: Williams RH, Wilson JD, eds. Williams Textbook of Endocrinology. 9th ed. Philadelphia: WB Saunders, 1998:1453-8

9. Jan M Wit. International Classification of Pediatric Endocrine Diagnoses. Horm Res Paediatr. 2016;86(3): 212-4. https://doi.org/10.1159/000448893

10. American Academy of Pediatrics. Recommendations for Preventive Pediatric Health Care Committee on Practice and Ambulatory Medicine. Pediatrics 2000;105:645-6. https://doi.org/10.1542/peds.105.3.645

11. Lacey KA, Parkin JM. Causes of short stature. A community study of children in Newcastle upon Tyne. Lancet 1974;1(7846):42-5. https://doi.org/10.1016/S0140-6736(74)93041-4

12. Voss LD. Growth hormone therapy for the short normal child: who needs it and who wants it? The case against growth hormone therapy. J. Pediatr. 2000;136:103-6. https://doi.org/10.1016/S0022-3476(00)90058-1

13. Voss LD, Mulligan J, Betts PR, Wilkin TJ. Poor growth in school entrants as an index of organic disease: the Wessex growth study. BMJ 1992;305:1400-2. https://doi.org/10.1136/bmj.305.6866.1400

14. Zafer Y, Kandemir N, Yordam N. Etiological distribution of short stature: Evaluation of 1013 cases. Journal of Child Health and Diseases 1999;42:205-13.

15. Demirel F, Bideci B, Camurdan MO, Arga M, Cinaz P. Etiological causes of short stature in children. Turkish Archives of Pediatrics 2005;40(1):39-43.

16. Fenton TR, Kim JH. A systematic review and metaanalysis to revise the Fenton growth chart for preterm infants. BMC Pediatr. 2013;13:59. https://doi.org/10.1186/1471-2431-13-59

17. Neyzi O, Bundak R, Darendeliler F, Günöz H. Büyüme Gelişme ve Bozuklukları. In: Neyzi O, Ertuğrul T, eds. Pediyatri Cilt 1, 4th ed, Istanbul: Nobel Tıp Kitapevleri, 2010:89-149.

18. Marshall WA, Tanner JM. Variations in pattern of pubrtal changes in girls. Arch Dis Child. 1969;44:291-303. https://doi.org/10.1136/adc.44.235.291

19. Marshall WA, Tanner JM. Variations in pattern of pubrtal changes in boys. Arch Dis Child. 1970;45:13-23. 
https://doi.org/10.1136/adc.45.239.13

20. Bundak R, Furman A, Gunoz H, Darendeliler F, Bas F, Neyzi O. Body mass index for Turkish children aged 6 to 18 years. Acta Paediatr 2006;95:194-8. https://doi.org/10.1080/08035250500334738

21. Neyzi O, Furman A, Bundak R, Gunoz H, Darendeliler F, Bas F. Growth references for Turkish children aged 6 to 18 years. Acta Paediatr. 2006;95:1635-41. https://doi.org/10.1080/08035250600652013

22. Neyzi O, Gunoz H, Furman A, Türk çocuklarında vücut ağırlığı, boy uzunluğu, baş çevresi ve vücut kitle indeksi referans değerleri. Çocuk Sağığı ve Hastalıkları Dergisi 2008;51:1-14.

23. WHO Multicentre Growth Reference Study Group. WHO Child Growth Standards Acta Paediatrica Supplement 2006;450.

24. De Onis M, Onyango AW, Borghi E, Siyam A, Nishida C, Siekmann J. Development of a WHO growth reference for school-aged children and adolescents. Bulletin of the World Health Organization, 2007;85(9):649-732. https://doi.org/10.2471/BLT.07.043497

25. McLaren DS, Read WWC. Classification of nutritional status in early childhood. Lancet 1972;2(7769):146-8. https://doi.org/10.1016/S0140-6736(72)91324-4

26. Tanner JM, Goldstein H, Whitwhouse RH. Standards for children's height at age 2-9 years allowing for height of parents. Arch Dis Child. 1970;45:755-62. https://doi.org/10.1136/adc.45.244.755

27. Bayley N, Pinneau SR. Tables for predicting adult height from skeletal age: revised for use with the GreulichPyle hand standart. J Pediatr. 1952;40:423-41. https://doi.org/10.1016/S0022-3476(52)80205-7

28. Şükür M, Baş F, Darendeliler F ve ark. Pediatrik endokrinoloji polikliniğine müracaat eden hastaların etiyolojik dağılımı: pilot çalışma. Pediatrik Endokrinoloji Kongresi Bildiri Özet Kitabı, 14-17 Eylül 2006, Konya, 2006:140.

29. Lindsay R, Feldkamp M, Harris D, Robertson J, Rallison M. Utah Growth Study: growth standards and the prevalence of growth hormone deficiency. J Pediatr. 1994;125:29-35.

https://doi.org/10.1016/S0022-3476(94)70117-2

30. Song KC, Jin SL, Kwon AR, Chae HW, Ahn JM, Kim DH, et al. Etiologies and characteristics of children with chief complaint of short stature. Ann Pediatr Endocrinol Metab. 2015;20:34-9.

https://doi.org/10.6065/apem.2015.20.1.34

31. Strufaldi MWL, da Silva EMK, Puccini RF. Follow-up of children and adolescents with short stature: the importance of the growth rate. Sao Paulo Med J. 2005;123(3):128-33. https://doi.org/10.1590/S1516-31802005000300008

32. Shiva S, Nikzad A. Etiology of short stature in East Azerbaijan, Iran. Iran J Pediatr. 2009;19:35-40.

33. Moayeri H, Aghighi Y. A prospective study of etiology of short stature in 426 short children and adolescents. Arch Iranian Med. 2004;7:23-7.

34. Lashari SK, Korejo HB, Memon YM. To determine frequency of etiological factors in short statured patients presenting at an endocrine clinic of a tertiary care hospital. Pak J Med Sci. 2014;30:858-61. https://doi.org/10.12669/pjms.304.4619

35. Zargar AH, Laway BA, Masoodi SR. An aetiological profile of short stature in the Indian subcontinent. J Pediatr Child Health. 1998;34:571-6. https://doi.org/10.1046/j.1440-1754.1998.00308.x

36. Papadimitriou A, Douros K, Papadimitriou DT, Kleanthous K, Karapanou O, Fretzayas A. Characteristics of the short children referred to an academic paediatric endocrine clinic in Greece. J Paediatr Child Health. 2012;48:263-7. https://doi.org/10.1111/j.1440-1754.2011.02256.x

37. Bhadada SK, Bhansali A, Ravikumar P, Kochhar R, Nain CK, Dutta $\mathrm{P}$, et al. Changing scenario in aetiological profile of short stature in India-growing importance of celiac disease: a study from tertiary care centre. Indian J Pediatr. 2011;78(1):41-4. https://doi.org/10.1007/s12098-010-0227-6

38. Tunçbilek E, Özgüç M. Application of medical genetics in Turkey. The Turkish Journal of Pediatrics 2007;49: 353-9.

39. Binder G. Short stature due to SHOX deficiency: Genotype, phenotype, and therapy. Horm Res Paediatr. 2011;75:81-89. https://doi.org/10.1159/000324105

40. Saenger P, Czernichow P, Hughes I, Reiter EO. Small for gestational age: Short stature and beyond. Endocr Rev. 2007;28(2):219-51. https://doi.org/10.1210/er.2006-0039

41. Chernausek SD. Mendelian genetic causes of the short child born small for gestational age. J Endocrinol Invest. 2006;29(1):16-20.

42. Jee YH. Genetics of Short Stature. Endocrinol Metab Clin North Am. 2017;46(2):259-81. https://doi.org/10.1016/j.ecl.2017.01.001 